\title{
The Genetic Relatedness of Proteolytic Clostridium botulinum Strains
}

\author{
By W. H. LEE AND H. RIEMANN \\ Department of Epidemiology and Preventive Medicine, University of \\ California, Davis, California 956I6, U.S.A.
}

(Accepted for publication 23 September 1970)

SUMMARY

DNA binding and competition tests indicate that the species Clostridium botulinum is composed of three groups with only 4 to I $8 \%$ DNA homology with each other. One group includes the proteolytic $C$. botulinum and $C$. sporogenes strains. The DNA isolated from seven proteolytic $C$. botulinum $\mathrm{A}, \mathrm{B}, \mathrm{F}$, and six $C$. sporogenes strains was 50 to $100 \%$ homologous to the C. botulinum A 62 DNA. Clostridium botulinum $\mathrm{C}$ and $\mathrm{D}$ strains form another group. Clostridium botulinum $\mathrm{C} 8613$ and $\mathrm{D} 8625$ strains have $38 \%$ homology with the $C$. botulinum $\mathrm{C} 573$ strain. The last group comprises the non-proteolytic $C$. botulinum B, E, and F strains reported previously. All the $C$. botulinum strains tested were related to only one of the three groups and no intermediate strain was detected.

\section{INTRODUCTION}

The relatedness of bacteria can be measured by phage infectivity, genetic transfer mechanisms and also by the degree of common DNA base sequence. Jones \& Sneath (1970) reviewed all these criteria with regard to bacterial taxonomy. Until now Clostridium botulinum genetics has not been developed and the relatedness of various toxic and non-toxic Clostridium strains is open to question. Smith \& Holdeman (I968) divided C. botulinum into three related groups, I, II, and III, on the basis of physiological and serological characteristics. Group I includes the proteolytic C. botulinum toxin types A, B and F strains. Group II includes the non-proteolytic C. botulinum toxin types B, E and F strains. Group III includes the $C$. botulinum toxin types $\mathrm{C}$ and D strains.

In our previous paper (Lee \& Riemann, 1970) the relatedness of various toxic and non-toxic strains of the group II of Clostridium botulinum was studied. We found that the $C$. botulinum strains have very similar guanosine + cytosine (GC) content (28 to $29 \%$ ) but they could be distinguished by DNA homology and competition. Kindler, Mager \& Grossowicz (1956) stated that the nutritional and biochemical requirements of $C$. sporogenes were indistinguishable from the proteolytic $C$. botulinum strains. In this paper the relatedness of toxic $C$. botulinum and $C$. sporogenes was tested. We also tested the relatedness of three $C$. botulinum $\mathrm{C}$ and $\mathrm{D}$ strains and the relatedness between the three groups of $C$. botulinum. 


\section{METHODS}

Cultures. The sources of many of the cultures have been described (Lee \& Riemann, I970). Additional strains of Clostridium botulinum A 79, B213, B I3983, and C. sporogenes PA 3679 were received from K. Ito (National Canners Association, Berkeley, California). Clostridium botulinum C86I 3 was obtained from W. P. Segner (Continental Can Co., Chicago, Illinois) and C.botulinum D (NCTC8265) was supplied by the National Collection of Type Cultures (Central Public Health Laboratory, Colindale, London, N.W. 9). Clostridium sporogenes 175 was obtained from L. S. McClung (Indiana University, Bloomington, Indiana) and C. sporogenes SC4I3I and SC4679 were obtained from L. DS. Smith (Virginia Polytechnic Institute, Blacksburg, Virginia). Clostridium sporogenes 10-I026 was supplied by V. R. Dowell (Anaerobic Bacteriology Laboratory, National Communicable Disease Center, Atlanta, Georgia). All the cultures received were re-isolated by streaking on blood agar and all the toxic isolates typed with specific botulinum toxin antiserum before they were grown for DNA isolation.

Medium and growth. Cells for DNA isolation were grown in the proteose-peptone and yeast extract (Difco) medium under conditions described (Lee \& Riemann, 1970). Clostridium botulinum C861 3 and D 8265 grew well in the above medium provided that the inoculum was grown in a fresh liver infusion (clear infusion from $500 \mathrm{~g}$. liver boiled in $1000 \mathrm{ml} . \mathrm{H}_{2} \mathrm{O}, \mathrm{pH} 8.5$ with $\mathrm{NaOH}$ plus $10 \mathrm{~g}$. Tryptose (Difco), I g. soluble starch, I g. $\mathrm{K}_{2} \mathrm{HPO}_{4}, \mathrm{I} \cdot 4 \mathrm{~g}$. $\mathrm{NaHCO}_{3}$ and $0.5 \mathrm{ml}$. mercaptoethanol). Radioactive DNA of C. botulinum A 62 was prepared from cells grown in $450 \mathrm{ml}$. Edamin $\mathrm{S}$ medium without Triton XI55 (Lee \& Riemann, 1970) and with $\mathrm{I} \cdot 75 \mathrm{mC}$ of $\left[{ }^{3} \mathrm{H}\right]$ thymidine added. Clostridium botulinum $\mathrm{C} 573$ did not grown in Edamin S medium. The radioactive DNA of $C$. botulinum c 573 was obtained from cells grown in $200 \mathrm{ml}$. of trypticase medium (50 g./l. trypticase (BBL), I g./l. soluble starch, I.4 g./l. $\mathrm{NaHCO}_{3}, 0.25 \mathrm{ml}$./1. Triton XI55, I mg./l. resazurin, $0.5 \mathrm{ml}$. mercaptoethanol, $\mathrm{pH} 7.2$ with $\mathrm{KOH}$ ). Growth was initiated by adding $3 \mathrm{ml}$. of inoculum grown in fresh liver infusion for I6 h. at $37^{\circ}$. After $3 \mathrm{~h}$. of visible growth, I mCi of $\left[{ }^{3} \mathrm{H}\right]$ thymidine and $\mathrm{I} \mathrm{mCi}$ of $\left[{ }^{3} \mathrm{H}\right]-$ adenosine were added, and the cells harvested $2 \mathrm{~h}$. later. Strict anaerobic technique (Cato et al. 1969), such as the use of inert gas to exclude air and prereduced medium, was necessary for the good growth of the $\mathrm{C}$ and $\mathrm{D}$ strains.

DNA isolation. Lysis and DNA isolation from Clostridium botulinum $\mathrm{C}$ and D strains were difficult and variable. Clostridium botulinum D 8265 was treated with $50 \mu \mathrm{g} . / \mathrm{ml}$. of penicillin $\mathrm{G}$ and D-cycloserine $2 \mathrm{~h}$. before harvest, and the cells were lysed in ice cold tris-SDS buffer (O.I M-tris (hydroxymethyl) aminomethane, I \% $\mathrm{Na}$ dodecyl sulphate, (SDS) $0 \cdot \mathrm{I} \mathrm{M}-\mathrm{NaCl}, \mathrm{pH} 9 \cdot 0$ with $\mathrm{HCl}$ ). The DNA of $C$. botulinum $\mathrm{C} 86 \mathrm{I} 3$ was obtained by grinding phenol-treated cells with alumina in tris-SDS buffer. The radioactive DNA of the $C$. botulinum $\mathrm{C} 573$ was obtained from cells treated with $\mathrm{I} \mathrm{mg} . / \mathrm{ml}$. of Pronase and lysozyme (Calbiochem, Los Angeles, California) in saline-EDTA buffer $(\mathrm{NaCl}$ 0. I5 $\mathrm{M}, \mathrm{Na}_{2}$ ethylenediaminetetra-acetate $\left(\mathrm{Na}_{2}\right.$ EDTA) $0.1 \mathrm{M}, \mathrm{pH} 9.0$ ) for $30 \mathrm{~min}$. at $37^{\circ}$ followed by addition of I \% SDS. The proteolytic C. botulinum and C. sporogenes strains always lysed by the above Pronase and lysozyme treatment and the DNA recovery was good.

The DNA was purified by the procedure of Miura (1967) including the isopropanol precipitation step. Clostridium perfringens DNA was purchased from Worthington 
Biochemical Corporation, Freehold, New Jersey. Escherichia coli DNA was a gift of P. Packnaud.

Analytical methods. DNA assay, binding, competition, $T_{\mathrm{m}}$ and thermal denaturation procedures have been described (Lee \& Riemann, 1970) but certain modifications were introduced. DNA binding and competition were assayed by a modified method of Denhardt's (I 966). Thirty $\mu \mathrm{g}$. of DNA were applied to each $25 \mathrm{~mm}$. Millipore HA filter. A length of 0.75 inch solid glass rod was inserted into the $\mathrm{I} \mathrm{ml}$. vial to reduce the liquid volume to $0.5 \mathrm{ml}$. and increase binding (Johnson \& Ordal, 1968). In the binding experiment, $0.45 \mathrm{ml}$. of preincubation mixture (PM) (Denhardt, I966) and $0.05 \mathrm{ml}$. of $0 . \mathrm{I} \times \mathrm{SSC}(\mathrm{NaCl} 0.15 \mathrm{M}$, sodium citrate $0.015 \mathrm{M}, \mathrm{pH} 7.2)$ containing the radioactive DNA were added to each vial. Two $\mu \mathrm{g}$. (8000 c.p.m.) of Clostridium botulinum A 62 DNA, or $2 \mu \mathrm{g}$. (8800 c.p.m.) of $C$. botulinum E MINN, or $0 \cdot 3 \mu \mathrm{g}$. (25,000 c.p.m.) of $C$. botulinum C 573 were added to each vial. In the competition experiment, $0.5 \mathrm{ml}$. of PM was removed after preincubation, and $0.28 \mathrm{ml}$. $0 . \mathrm{I} \times \mathrm{SSC}$ containing $250 \mu \mathrm{g}$. unlabelled, I $\mu \mathrm{g}$. homologous radioactive $C$. botulinum A62 DNA together with $0.12 \mathrm{ml}$. of Io $\times$ SSC was added to each vial. Clostridium botulinum $\mathrm{C} 573$ competition was carried out with $250 \mu \mathrm{g}$. of unlabelled DNA and $0.3 \mu \mathrm{g}$. of homologous radioactive C573 DNA. Seven replicates were used in the binding experiments but each competition experiment was made only once or twice due to a limited amount of DNA available. Incubation was carried out at $66^{\circ}\left(T_{\mathrm{m}} 8 \mathrm{I}^{\circ}\right)$ for $\mathrm{I} 2 \mathrm{~h}$.

\section{RESULTS}

DNA binding and competition. The optimum conditions for DNA duplex formation on filters were tested. Maximum binding (c.p.m.) or saturation of the filter was reached when I $5 \mu \mathrm{g}$. of Clostridium botulinum A 62 or A 78 DNA was applied to each filter. To be safe, $30 \mu \mathrm{g}$. of DNA was used. DNA duplex formation was directly proportional to the amount of radioactive $C$. botulinum A62 DNA added to the solution up to $3 \mu \mathrm{g}$. level. $\left[{ }^{3} \mathrm{H}\right]$ thymidine uptake by $C$. botulinum $\mathrm{A} 62$ was very poor and was not enhanced by the addition of Triton XI55 detergent. The best preparation contained only 4000 c.p.m./ $\mu$ g. of DNA. The DNA duplex of $C$. botulinum on filters was stable and showed a thermal denaturation curve similar to that of the native DNA. The $T_{\mathrm{m}}$ of the radioactive duplex on filters was $76.6^{\circ}$ as compared to the $T_{\mathrm{m}}$ of $8 \mathrm{I}^{\circ}$ of the native DNA.

Results of percent DNA binding and competition of 28 strains relative to the Clostridium botulinum A 62 DNA are presented in Table $\mathrm{I}$. The average of A62 homologous DNA binding was 4 I5O c.p.m., and the standard deviation of each set was 5 to $26 \%$. In competition experiments the binding was reduced from 3940 to II 30 c.p.m. with $250 \mu \mathrm{g}$. of unlabelled homologous A62 DNA.

Maximum binding was achieved when $30 \mu \mathrm{g}$. of Clostridium botulinum $\mathrm{C} 573$ or D 8265 DNA was applied to each filter, but $60 \mu \mathrm{g}$. of c8613 DNA was used. Very little (40 $\mu \mathrm{g}$.) of radioactive C. botulinum $\mathrm{C} 573$ DNA was isolated because of extensive degradation of the DNA during lysis of the cells. The amount of DNA recovered was just adequate for the experiment presented in Table 2. The average count of seven replicates of $\mathrm{C} 573$ homologous DNA binding was $3633 \pm 923$ c.p.m. The binding was reduced from 5030 to I060 c.p.m. with $250 \mu \mathrm{g}$. of unlabelled homologous c 573 DNA in competition experiments. 
Optimum conditions for binding with Clostridium botulinum E MINN were tested previously (Lee \& Riemann, 1970). The relatedness of the C and D strains with the E MINN strains is presented in Table 3.

Table I. Percent binding and competition of DNA of various strains relative to $\left[{ }^{3} \mathrm{H}\right] \mathrm{DNA}$ of Clostridium botulinum $\mathrm{A} 62$

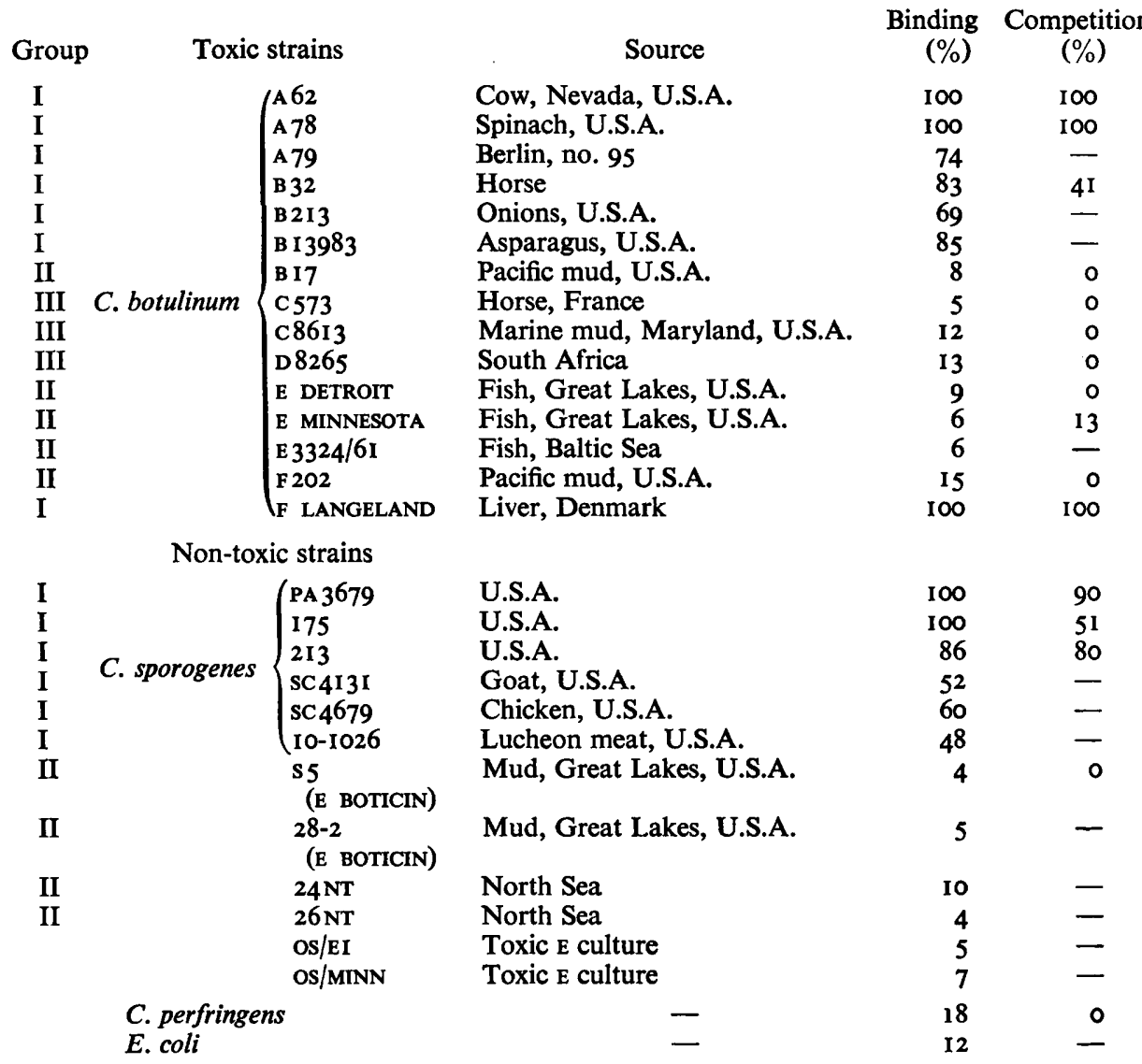

Table 2. Percent binding and competition of DNA from various strains relative to $\left[{ }^{3} \mathrm{H}\right] D N A$ of Clostridium botulinum $C 573$ and their $G C$ contents

\begin{tabular}{|c|c|c|c|c|c|}
\hline Group & \multicolumn{2}{|c|}{ Strains } & $\begin{array}{l}\text { GC } \\
(\%)\end{array}$ & $\begin{array}{c}\text { Binding } \\
(\%)\end{array}$ & $\begin{array}{c}\text { Competition } \\
(\%)\end{array}$ \\
\hline III & \multirow{5}{*}{ C. botulinum } & (c573 & $27 \cdot 6$ & 100 & 100 \\
\hline III & & c8613 & $27 \cdot 8$ & 38 & 34 \\
\hline III & & D8265 & $27 \cdot 2$ & 39 & 35 \\
\hline I & & A 62 & $28.5^{*}$ & 18 & - \\
\hline II & & E MINN & $27 \cdot 9^{*}$ & 5 & - \\
\hline \multicolumn{3}{|c|}{ C. perfringens } & - & 24 & - \\
\hline
\end{tabular}




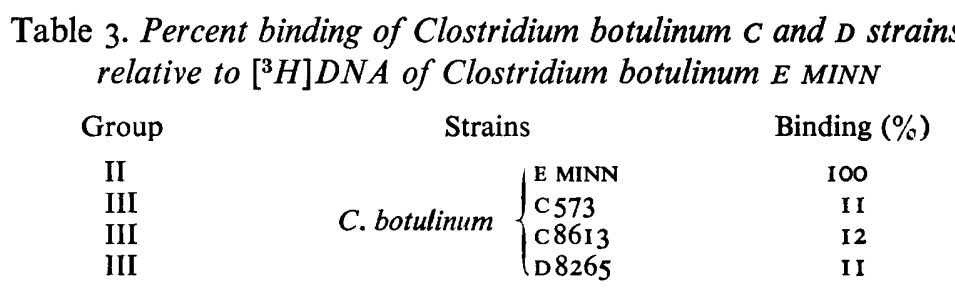

\section{DISCUSSION}

The above results confirm the observations of Kindler et al. (1956) that Clostridium sporogenes and the proteolytic group I or $C$. botulinum are genetically related. Three of the $C$. sporogenes strains tested have 86 to $100 \%$ common base sequence with the C. botulinum A 62 strain and the results of competition experiments generally confirm the DNA binding data (Table I). We will attempt to determine if there are measurable DNA binding error or differences between these highly related $C$. sporogenes and C. botulinum strains. Both group I and II (Lee \& Riemann, I970) of C. botulinum have 50 to $100 \%$ DNA homology within the group.

The three strains of group III of Clostridium botulinum showed limited (38\%) homology with each other (Table 2). The cytosine plus guanine content of their DNA is very similar to the $C$. botulinum A62 and E MINN strains (Table 2). Many non-toxic variants of $C$. botulinum $\mathrm{C}$ and $\mathrm{D}$ strains have been reported (Smith \& Holdeman I968; Inoue \& Iida, 1970) and most probably group III of $C$. botulinum also contains related toxic and non-toxic strains.

The relatedness between the groups, I, II, and III is very limited and all the strains tested were related to only one of the group (Tables I and 2) (Lee \& Riemann, 1970). The DNA binding between groups was only 4 to $18 \%$. By comparison the binding of Clostridium botulinum A62 DNA to the completely unrelated Escherichia coli DNA was $12 \%$ (Table I) and that of the C. botulinum E MINN to Micrococcus lysodeikticus was $4 \%$ (Lee \& Riemann, 1970). Walker \& Batty (1967) found serological crossreactions within the three groups of $C$. botulinum but not between the groups. It is apparent from our studies and the study of others that the three groups of C. botulinum are not related to each other as a single species and they have little common DNA base sequence.

The ribosomal RNA (rRNA) base sequence is conserved in bacterial evolution and rRNA/DNA homology is used as a broader measurement of bacterial relatedness (Doi \& Igarashi, I 965). In view of the heterogeneity we have observed, the relatedness of various Clostridium species may be best determined by rRNA/DNA binding tests. The relatedness of Clostridium and Bacillus species has not been tested. It is possible that Clostridium is an oxygen-sensitive mutant of Bacillus, analogous to the oxygensensitive hemin-deficient Escherichia coli mutant isolated by Beljanski \& Beljanski (I957). However, the GC content of C. botulinum DNA is $28 \%$ (Table 2), which is lower than the minimum Bacillus GC content of $32 \%$ (Hill, I966). This difference in DNA composition makes it difficult to relate $C$. botulinum with any Bacillus species.

The relatedness of Clostridium sporogenes and $C$. botulinum group I strains naturally raises the question of possible transfer of toxigenesis from the toxic to non-toxic strains. Inoue \& lida (1970) reported the conversion of a non-toxic strain to a toxic C. botulinum 
$\mathrm{C}$ strain by filterable phage-like particles. Lytic phages of $C$. sporogenes but not the proteolytic C. botulinum have been reported (Betz \& Anderson, 1967).

We wish to thank Sally A. Myers for $T_{\mathrm{m}}$ and radioactive determinations. This study was supported by U.S. Public Health Grant UI 000262-03 and sponsored by the Food Protection and Toxicology Center of the University of California, Davis.

\section{REFERENCES}

Beluanski, M. \& BeljansKi, M. (1957). Sur la formation d'enzymes respiratoires chez un mutant d'Escherichia coli streptomycino-resistant et auxotrophe pour l'hémine. Annales de l'Institut Pasteur, Paris 92, 396-412.

BETZ, J. V. \& ANDERSON, K. E. (1967). Isolation and characterization of bacteriophages active on Clostridium sporogenes. Journal of Bacteriology 87, 408-415.

Cato, E. P., Cummins, C. S., Holdeman, L. V., Johnson, J. L., Moore, W. E. C., Smirert, R. M. \& SMITH, L. DS. (1969). Outline of Clinical Methods in Anaerobic Bacteriology. Blacksburg, Virgina: The Virginia Polytechnic Institute Anaerobic Laboratory.

DenhaRd, D. T. (1966). A membrane filter technique for the detection of complementary DNA. Biochemical and Biophysical Research Communications 23, 64I-646.

DoI, R. H. \& IgARASHI, R. T. (1965). Conservation of ribosomal and messenger ribonucleic acid cistrons in Bacillus species. Journal of Bacteriology 90, 384-390.

HILL, L. R. (1966). An index to deoxyribonucleic acid base composition of bacterial species. Journal of General Microbiology 44, 419-437.

INOUE, K. \& IIDA, H. (1970). Conversion of toxigenicity in Clostridium botulinum type C. Japanese Journal of Microbiology 14, 87-89.

Johnson, J. L. \& ORDAL, E. J. (1968). Deoxyribonucleic acid homology in bacterial taxonomy: effect of incubation temperature and reaction specificity. Journal of Bacteriology 95, 893-900.

JoNes, D. \& SNEATH, P. H. A. (1970). Genetic transfer and bacterial taxonomy. Bacteriological Reviews 34, 40-8I.

Kindler, S. H., MAGER, J. \& Grossowicz, N. (1956). Nutritional studies with the Clostridium botulinum group. Journal of General Microbiology 15, 386-393.

LEE, W. H. \& RIEMANN, H. (1970). Correlation of toxic and nontoxic strains of Clostridium botulinum by DNA composition and homology. Journal of General Microbiology 60, I I 7-I 23.

MiURA, K.-I. (1967). Preparation of bacterial DNA by phenol-ph9-RNAses method. Methods in Enzymology 12A, 543-545.

Smith, L. DS. \& Holdeman, L. V. (1968). The Pathogenic Anaerobic Bacteria. Springfield, Illinois: Charles C. Thomas.

WALKER, P. D. \& BATTY, I. (1967). The serology of $C$. botulinum with reference to fluorescent staining. In Botulism 1966, pp. 482-493. Edited by M. Ingram \& T. A. Roberts. London: Chapman and Hall. 